\title{
Developing English Abilities of Autonomous Learning for Undergraduates in the Environment of Ecological Affordance
}

\author{
$\mathrm{Ji}_{\text {Song }}{ }^{1}$ \\ ${ }^{1}$ College English Teaching Department, Dezhou University, Dezhou, Shandong, China \\ Correspondence: Ji Song, College English Teaching Department, Dezhou University, Dezhou, Shandong, China.
}

Received: June 6, 2020

Accepted: June 26, 2020

Online Published: June 27, 2020

doi: $10.5539 /$ elt.v13n7p104

URL: https://doi.org/10.5539/elt.v13n7p104

\begin{abstract}
The research investigates undergraduates' English abilities of autonomous learning in the environment of ecological affordance. It proves that their abilities are significantly different before and after independent learning in one semester, and they can actively try their own learning strategies and achieve good results in English learning, which reflects the success of cultivating the ability of autonomous learning. And it also holds that it is a good ecological affordance when learners could sense and understand abundant learning resources under their teachers' effective guidance, and thus arouse enough enthusiasm for English learning to guarantee the quality of College English instruction.
\end{abstract}

Keywords: autonomous learning, ecological affordance, learning resources, College English

\section{Introduction}

Since the late 1990s, under the development of the sociocultural school in second language acquisition (Lantolf, 2006; Atkinson, 2011), its ecological research direction has been also flourishing. Affordance is an ecological psychology term claimed by American psychologist James J. Gibson and defined as "The affordances of the environment are what it offers the animal, what it provides or furnishes, either for good or ill (Gibson, 1979)". Ecological affordance focuses on the relationship between human beings and their environment, especially the development of people's language abilities in the environment (van Lier, 2004). It is the result of the interaction of language users, environment and language (Aronin \& Singleton, 2012). The language user perceives learning resources and interactive learning opportunities provided by the environment, interprets them, takes corresponding language learning actions and then converts them into affordance.

The research on ecological affordance is mainly based on the theoretical argumentation (Kramsch, 2000; Steffensen \& Fill, 2014). At present, main researches focus on multilingual learning and multilingual phenomenon (Singleton \& Aronin, 2007), language learning experience in overseas study (Allen, 2010), computer assisted language teaching (McNeil, 2014), language learning in and out of class and self-directed language learning (Cotterall \& Murray, 2009; Menezes, 2011; Murray \& Fujishima, 2013; Peng, 2011; Qin \& Dai, 2015; Huang, Long, \& Teng, 2018), research and design of learning environment (He \& Zhu, 2012; Li \& $\mathrm{Wu}, 2016$; Zhou, 2017; Li, Wu, \& Yang, 2018), professional development of foreign language teachers (Cheng $\& \mathrm{Wu}, 2016)$. Overall, the studies are not specific on the understanding and definition of ecological affordance and has not formed into the whole theoretical system. There is not enough research innovation and correspondingly no solid empirical data to verify their theoretical researches.

So far, there is no set definition of autonomous learning ability among academic research circle. Holec (1981) defined it as an ability that learners should manage their learning, which includes the determination of learning objectives and learning content, the selection of learning methods, the monitoring of learning process, and the evaluation of learning results. From the perspective of English learners, Xu, Peng \& Wu (2004) interpreted that it should cover the setting and planning of learning objectives, the use of learning strategies, the monitoring and evaluation of learning process, and some other dimensions. Although without set concept, researchers totally agree that autonomous learners must carry out self-monitoring management and must be independent in the process of learning.

In recent years, researchers (O'Reilly, 2014; Duarte, Leite, \& Mouraz, 2015) found that learning motivation would significantly affect the students' learning autonomy. The higher the learning motivation, the stronger the 
study enthusiasm, and they would be responsible for their own learning and have effective regulation of that. Wu \& Zhang (2009), Tan \& Zhang (2015) believe that learning strategies have a positive prediction on autonomous learning ability. Ramnarain \& Hobden (2015) hold that the transformation of teachers' role contributes to students' development of their independent learning. Teachers can improve students' autonomous learning ability by transferring classroom activities to them (Feryok, 2013; Guan \& Li, 2014). Chen (2014) shows that the independent support of teachers can influence students' motivation level and the degree of learning involvement. Hale (2015) confirms that learners' self-evaluation can cultivate their ability of autonomous learning. Qin (2015) proposes to use corpus to improve students' independent learning ability. In addition, language portfolio (Little, 2009) and students' portfolio (Jirapa, 2014) can also enhance students' ability to learn independently. Integrating theory and practice, the researches mentioned above discuss the various factors affecting the ability of autonomous learning and different research tools. However, their studies cover narrow areas and are unable to support their assumptions mutually.

The former studies were carried out respectively in the field of ecological affordance and autonomous learning ability, but this research will combine the two areas and thus enrich related theory study and broaden the research approach.

\section{Research Content}

The fundamental aim of developing English abilities of autonomous learning in the environment of ecological affordance is to make efficient conversion of good affordance matched with students' learning performance, which caters to their learning needs and make them confront with positive affordance as much as possible through teachers' effective learning guidance and abundant learning resources. It will arouse the learners' specific learning behavior and improve their ability of autonomous learning, and eventually lead to form a whole ecosystem which goal and function are unified and coordinated. In a word, it should enable students to sense and understand the abundant learning environment and stimulate their enthusiasm for learning to improve the quality of College English instruction.

The research was conducted among the undergraduates of Grade 2016 majored in transportation in Dezhou University. They are sophomore and take a College English course of viewing, listening and speaking involved two class periods in a week in a multimedia classroom. There are 54 students in the class, including 30 boys and 24 girls. Under the guidance of their teacher, they were required to use their own mobile phones to carry out autonomous learning out of class for 20 minutes from Monday to Friday every week in a semester. The learning contents are Unipus APP, VOA Special English APP, and BaiCiZhan APP.

Owing to taking College English Test Band 4 at the end of the semester, the teacher made planning for the students' autonomous learning. For the first APP, they should preview and review audio and video materials related to their coursebook, and also do some listening, reading and writing exercises for their coming test. For the second one, they need to review vocabularies of Band 4 by vivid cartoon pictures and example sentences. And the third one, that is to develop their listening skills of news report by the latest world news in special English for those whose English level is not good enough. And the last one, the purpose is to try to expand their horizons by many short reading materials for the skillful learners. Thus, it forms a good ecological affordance with enough learning resources which meet students' cognitive features, and teachers' proper guidance.

\section{Research Methods}

At the beginning and end of the semester, 54 students in the class were respectively given questionnaires to investigate their English abilities of autonomous learning in the environment of ecological affordance. The measurement was revised based on the questionnaire compiled by Xu, Peng \& Wu (2004). It was closed-ended and employed a five-point Likert-scale ranging from totally disagreed, disagreed, neutral, agreed to totally agreed. It consisted of 20 items belonging to four major categories: planning, learning methods, learning resources and evaluating. Each category consisted of 5 different items to measure the students' abilities of independent learning. The collected 108 questionnaires were totally valid. After the final investigation, 8 students in the class were asked to have a semi-structured interview one by one, and the subjects were selected according to maximum variation sampling method. Through the data encoding of interviewees' recordings, it helped to explain and analyze the statistical data of questionnaires, which made the conclusion more convincing.

\section{Data Analyses}

The researcher used SPSS 22.0 data analysis software to process the questionnaire data. 
Table 1. Make a study plan according to teacher's guidance

\begin{tabular}{lllc}
\hline \multicolumn{1}{c}{ Items } & $N$ & Mean & Std. Deviation \\
\hline $\begin{array}{l}\text { Besides the study tasks assigned by the } \\
\text { teacher, I also make my own study plan. }\end{array}$ & 54 & 4.19 & 0.440 \\
$\begin{array}{l}\text { I will set my learning goals according to my } \\
\text { own situation. }\end{array}$ & 54 & 4.21 & 0.566 \\
$\begin{array}{l}\text { If necessary, I will adjust my study plan. } \\
\text { I will plan my study time. }\end{array}$ & 54 & 3.98 & 0.665 \\
$\begin{array}{l}\text { I will set my learning goals according to the } \\
\text { requirements of the teacher's planning. }\end{array}$ & 54 & 4.37 & 0.556 \\
$\begin{array}{l}\text { Valid N (listwise) } \\
\text { Average Mean }\end{array}$ & 54 & 4.13 & 0.482 \\
\hline
\end{tabular}

In the first survey, students scored lowest on the five items in Table 1, only 3.346 points. After one-term autonomous learning, though the score in the four categories was still low, it rose to 4.176 points more than the researcher's expectation. This shows that students attach great importance to study plan gradually. They can make reasonable learning plans and goals, and adjust according to the situation, which is the embodiment of improved ability of autonomous learning.

Table 2. Use learning methods that suitable for one's own

\begin{tabular}{llcc}
\hline \multicolumn{1}{c}{ Items } & $N$ & Mean & Std. Deviation \\
\hline I know general learning strategy. & 54 & 4.12 & 0.423 \\
$\begin{array}{l}\text { In my study, I am capable to conduct } \\
\text { effective preview. }\end{array}$ & 54 & 4.46 & 0.634 \\
$\begin{array}{l}\text { I can make effective review in my study. } \\
\text { I can take notes effectively in my study. }\end{array}$ & 54 & 4.60 & 0.491 \\
$\begin{array}{l}\text { In my study, I can effectively strengthen my } \\
\text { memory. }\end{array}$ & 54 & 4.63 & 0.482 \\
$\begin{array}{l}\text { Valid N (listwise) } \\
\text { Average Mean }\end{array}$ & 54 & 4.25 & 0.756 \\
\hline
\end{tabular}

Table 2 shows that, owing to the reinforcement of preview, review and summary and rigid requirements by their teacher, most of the students did very well in learning strategy. Good learning methods can make better learning effect, and thus, in turn, encourage them to learn more. In the following interview with one student, his words also testified the point of view.

"In the past, my English study was much casual, and that depended on my mood and my time, when there was free time, I would learn. Now, under the guidance of the teacher, I gradually develop the habit, that is, study in fixed time every day, preview, review, and feel that everything is getting better, and the English scores have improved." 
Table 3. Learn how to use and find resources

\begin{tabular}{lllc}
\hline \multicolumn{1}{c}{ Items } & $N$ & Mean & Std. Deviation \\
\hline $\begin{array}{l}\text { In the process of learning, I can always find } \\
\text { the resources I want. }\end{array}$ & 54 & 3.88 & 0.466 \\
$\begin{array}{l}\text { In the process of learning, I have many ways } \\
\text { to find resources. }\end{array}$ & 54 & 4.46 & 0.634 \\
$\begin{array}{l}\text { In the process of learning, I can communicate } \\
\text { effectively with the classmates who study } \\
\text { with me together. }\end{array}$ & 54 & 3.96 & 0.337 \\
$\begin{array}{l}\text { In the process of learning, I can raise the } \\
\text { effective questions. }\end{array}$ & 54 & 3.87 & 0.482 \\
$\begin{array}{l}\text { I can realize what resources I need and make } \\
\text { efforts to find that. }\end{array}$ & 54 & 3.96 & 0.678 \\
$\begin{array}{l}\text { Valid N (listwise) } \\
\text { Average Mean }\end{array}$ & 54 & & \\
\hline
\end{tabular}

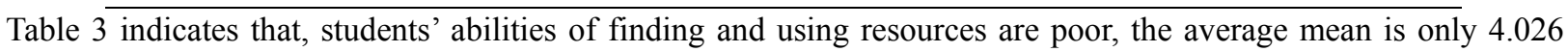
points though the teacher gave some guidance. This states that students still have some problems in searching and using learning resources and they cannot flexibly adjust their learning methods and make full use of resources according to actual condition. This will be the focus of the teacher's instruction in the future.

Table 4. Monitor and evaluate the learning process

\begin{tabular}{lllc}
\hline \multicolumn{1}{c}{ Items } & $N$ & Mean & Std. Deviation \\
\hline I will arrange my learning process properly. & 54 & 4.13 & 0.341 \\
I will apply my new knowledge in practice. & 54 & 4.29 & 0.453 \\
$\begin{array}{l}\text { I will be studying on schedule. } \\
\begin{array}{l}\text { I can select the effective learning approach to } \\
\text { make myself a better learner. }\end{array}\end{array}$ & 54 & 4.71 & 0.453 \\
$\begin{array}{l}\text { When I finish a study task, I will check the } \\
\text { completion of my pre-determined learning } \\
\text { plan. }\end{array}$ & 54 & 4.19 & 0.440 \\
$\begin{array}{l}\text { Valid N (listwise) } \\
\text { Average Mean }\end{array}$ & 54 & 3.81 & 0.941 \\
\end{tabular}

The average mean in Table 4 increases to 4.226 points from original 3.496 points. It argues that students enhance their commitment to study in the process of learning and they can have more control over the schedule of autonomous learning through effective means, such as peer exchanges, comparison with study plan, and new knowledge learning by prior ones.

Paired-samples $t$ Test was used to verify whether the difference was significant before and after the students' autonomous learning. 
Table 5. Significant difference analysis

\begin{tabular}{|c|c|c|c|c|c|c|}
\hline Categories & Week & $N$ & Mean & $\begin{array}{c}\text { Std. } \\
\text { Deviation }\end{array}$ & $t$ & Sig.(2-tailed) \\
\hline \multirow{2}{*}{$\begin{array}{l}\text { make a study plan } \\
\text { according to teacher's } \\
\text { guidance }\end{array}$} & 1 & 54 & 3.3462 & 0.39430 & \multirow{2}{*}{-13.961} & \multirow{2}{*}{.000} \\
\hline & 16 & 54 & 4.1769 & 0.24940 & & \\
\hline \multirow{2}{*}{$\begin{array}{l}\text { use learning methods } \\
\text { that suitable for one's } \\
\text { own }\end{array}$} & 1 & 54 & 3.5538 & 0.40315 & \multirow{2}{*}{-12.450} & \multirow{2}{*}{.000} \\
\hline & 16 & 54 & 4.4115 & 0.31787 & & \\
\hline \multirow{2}{*}{$\begin{array}{l}\text { learn how to use and } \\
\text { find resources }\end{array}$} & 1 & 54 & 3.5346 & 0.37724 & \multirow{2}{*}{-8.167} & \multirow{2}{*}{.000} \\
\hline & 16 & 54 & 4.0269 & 0.26280 & & \\
\hline \multirow{2}{*}{$\begin{array}{l}\text { monitor and evaluate } \\
\text { the learning process }\end{array}$} & 1 & 54 & 3.4962 & 0.38499 & \multirow{2}{*}{-11.092} & \multirow{2}{*}{.000} \\
\hline & 16 & 54 & 4.2269 & 0.25980 & & \\
\hline
\end{tabular}

Table 5 shows that the students' abilities were significantly different before and after autonomous learning at $p$-value $<.01$ (two-tailed). This indicates the effectiveness of their independent learning after one semester. Comparing the data of standard deviation, the latter one is smaller than the former in each category, which means that the gap has narrowed after autonomous learning. At the beginning, some students had high ability of autonomous learning behavior, but some low, and the difference between the high and the low was bigger. However, at the end of the semester, the gap shrank and the value between the means improved, which states that most students have increased their autonomous learning ability.

\section{Discussion and Conclusion}

After the experimentation in one semester, the students' English abilities of autonomous learning improved significantly. They can actively try their own learning strategies and achieve good results in English learning, which reflects the success of cultivating the ability of autonomous learning.

Their attitude to English learning has changed and become more correct. They know that the purpose of learning English should be improving the comprehensive ability in the process of knowledge transmission and learning, that is, to realize the development of their whole self. As a result, they begin to establish their dominant position in study and could set their own learning plans and learning goals. Even without the guidance of a teacher, some of them can continue to study according to their own plans. In addition, they can actively use many new tools to help learning English and find learning resources to arouse the interests of language learning. When communicating with peers, they can also exchange English learning experience and learning methods to make progress in the interaction.

Their habits of English learning have improved. Since they established their learning goals and enhanced the study planning, quite a lot of them developed the habits of previewing, reviewing and self-study after class. During the process of learning, they can find problems, explore ways to solve them, summarize learning experience and make reflection to adjust their study plan, learning methods etc. in the direction of self-regulation.

This research also suggests that it is a good ecological affordance when learners could sense and understand abundant learning resources under their teachers' effective guidance, and thus arouse enough enthusiasm for English learning to guarantee the quality of College English instruction.

\section{References}

Allen, H. (2010). Interactive contact as linguistic affordance during short-term study abroad: Myth or reality. Frontiers: The Interdisciplinary Journal of Study Abroad, 19(1), 1-26. https://doi.org/10.36366/frontiers.v19i1.271

Aronin, L. \& Singleton, D. (2012). Affordances theory in multilingualism studies. Studies in Second Language Learning and Teaching, 2(3), 311-331. https://doi.org/10.14746/ssllt.2012.2.3.3

Atkinson, D. (2011). Alternative approaches to second language acquisition. Oxford: Routledge. https://doi.org/10.4324/9780203830932

Chen, J. W. (2014). Effect of family's social class and autonomous motivation on the relationship between teacher's autonomy support and junior middle school students' study (Unpublished doctoral dissertation). 
Central China Normal University, Wuhan, China).

Cheng, X. \& Wu, L. (2016). The affordances of teacher professional learning communities: A case study of a Chinese secondary school. Teaching and Teacher Education, 58(6), 54-67. https://doi.org/10.1016/j.tate.2016.04.008

Cotterall, S. \& Murray, G. (2009). Enhancing metacognitive knowledge: Structure, affordances and self. System, 37(1), 34-45. https://doi.org/10.1016/j.system.2008.08.003

Duarte, M., Leite, C. \& Mouraz, A. (2015). The effect of curricular activities on learner autonomy: The perspective of undergraduate mechanical engineering students. European Journal of Engineering Education, 41(1), 91-104. https://doi.org/10.1080/03043797.2015.1056101

Feryok, A. (2013). Teaching for learner autonomy: The teacher's role and sociocultural theory. Innovation in Language Learning and Teaching, 7(3), 213-225. https://doi.org/10.1080/17501229.2013.836203

Gibson, J. J. (1979). The ecological approach to visual perception. Hillsdale, NJ: Erlbaum.

Guan, C. \& Li, F. P. (2014). The investigation and analysis of teachers' involvement in students' autonomous learning. Open Journal of Modern Linguistics, 4(4), 512-516. https://doi.org/10.4236/ojml.2014.44044

Hale, C. C. (2015). Self-assessment as academic community building: A study from a Japanese liberal arts university. Language Testing in Asia, 5(1), 1-12. https://doi.org/10.1186/s40468-014-0010-0

He, B. \& Zhu, Z. T. (2012). The research on the design of learning environment affordance. E-Education Research, 235(11), 30-38.

Holec, H. (1981). Autonomy in foreign language learning. Oxford: Pergamon.

Huang, J., Long, N. N. \& Teng, F. (2018). Affordances and foreign language education. Foreign Languages and Their Teaching, 298(1), 39-52.

Jirapa, M. L. A. (2014). Investigating the use of student portfolios to develop students' metacognition in English as a foreign language learning. Journal of Language Teaching and Research, 5(1), 46-55. https://doi.org/10.4304/jltr.5.1.46-55

Kramsch, C. (2000). Social discursive construction of self in L2 learning. In J. P. Lantolf (Ed.), Sociocultural theory and second language learning, 133-154. Oxford: Oxford University Press.

Lantolf, J. (2006). Language emergence: implications for applied linguistics—a sociocultural perspective. Applied Linguistics, 27(4), 717-728. https://doi.org/10.1093/applin/aml034

Li, T. T. \& Wu, F. T. (2016). A new analysis of the ecological structure of online learning environment based on the concept of affordance. E-Education Research, 283(11), 51-59.

Li, T. T., Wu, F. T. \& Yang, S. Q. (2018). Research on ecological design methods of online learning environments: A "1 mainline, 2 matches" design model based on affordance. Journal of Distance Education, 245(2), 76-86.

Little, D. (2009). Language leaner autonomy and the European Language Portfolio: Two L2 English example. Language Teaching, 42(2), 222-233. https://doi.org/10.1017/s0261444808005636

McNeil, L. (2014). Ecological affordance and anxiety in an oral asynchronous computer-mediated environment. Language Learning \& Technology, 18(1), 142-159.

Menezes, V. L. (2011). Affordances for language learning beyond the classroom. In P. Benson \& H. Reinders (Eds.), Beyond the language classroom, 59-71. New York: Palgrave MacMillan. https://doi.org/10.1057/9780230306790_6

Murray, G. \& Fujishima, N. (2013). Social language learning spaces: Affordances in a community of learners. Chinese Journal of Applied Linguistics, 36(1), 140-156. https://doi.org/10.1515/cjal-2013-0009

O'Reilly, N. E. (2014). Correlations among perceived autonomy support, intrinsic motivation, and learning outcomes in an intensive foreign language program. Theory and Practice in Language Studies, 4(7), 1313-1318. https://doi.org/10.4304/tpls.4.7.1313-1318

Peng, J. (2011). Changes in language learning beliefs during a transition to tertiary study: The mediation of classroom affordances. System, 39(3), 314-324. https://doi.org/10.1016/j.system.2011.07.004

Qin, L. L. \& Dai, W. D. (2015). Investigating affordances in College English learning environment from an ecological perspective. Modern Foreign Languages, 38(2), 227-237.

Qin, Q. X. (2015). The corpus linguistics based study of cultivating autonomous learning ability for English 
learners. Studies in Literature and Language, 11(3), 18-21.

Ramnarain, U. \& Hobden, P. (2015). Shifting South African learners towards greater autonomy in scientific investigations. Journal of Curriculum Studies, 47(1), 94-121. https://doi.org/10.1080/00220272.2014.966153

Singleton, D. \& Aronin, L. (2007). Multiple language learning in the light of the theory of affordances. Innovation in Language Learning and Teaching, 1(1), 83-96. https://doi.org/10.2167/illt44.0

Steffensen, S. V. \& Fill, A. (2014). Ecolinguistics: the state of the art and future horizons. Language Sciences, 41, 6-25. https://doi.org/10.1016/j.langsci.2013.08.003

Tan, X. \& Zhang, Z. H. (2015). Relationships among language learning strategies, learner autonomy and CET-4 scores. Foreign Language Learning Theory and Practice, 1, 59-65+88.

van Lier, L. (2004). The ecology and semiotics of language learning: A sociocultural perspective. Boston: Kluwer Academic. https://doi.org/10.1007/1-4020-7912-5

Wu, X. Y. \& Zhang, Q. Z. (2009). Exploring the relationship among self-efficacy, learning strategies, self-regulated learning and academic achievement for English-major students. Foreign Language Education, 30(3), $43-46+62$.

Xu, J. F., Peng, R. Z. \& Wu, W. P. (2004). The investigation and analysis of English ability of autonomous learning for non-English majors. Foreign Language Teaching and Research, 36(1), 64-68.

Zhou, Y. (2017). The study of College English learning environment from the perspective of affordance. Foreign Language Education, 38(6), 70-73.

\section{Copyrights}

Copyright for this article is retained by the author(s), with first publication rights granted to the journal.

This is an open-access article distributed under the terms and conditions of the Creative Commons Attribution license (http://creativecommons.org/licenses/by/4.0/). 